\title{
The Effect of Competency, Compensation and Work Discipline on Employee Performance in Service Division PT. United Motors Center Suzuki Surabaya
}

Azmi Fachriyah ${ }^{1}$, Yulyar Kartika Wijayanti ${ }^{*}$
${ }^{1,2}$ Faculty of Economics and Business, 17 gustus 1945 Surabaya University

e-mail: yuliar@untag-sby.ac.id ${ }^{2}$

* Corresponding Author: E-mail: yuliar@untag-sby.ac.id

\begin{tabular}{|c|c|}
\hline ARTICLE INFO & ABSTRACT \\
\hline Received June 2021 & The purpose of this study is to determine whether competence, \\
\hline Accepted June 2021 & compensation and work discipline partially and simultaneously \\
\hline Published July 2021 & affect employee performance in PT. United Motors Centre Suzuki \\
\hline $\begin{array}{lr}\text { Keywords: } & \text { Competence, } \\
\text { Compensation, } & \text { Employee } \\
\text { Performance, } & \text { Work } \\
\text { Discipline. } & \end{array}$ & $\begin{array}{l}\text { Ahmad Eigis Surabaya. Types research is explanatory research } \\
\text { with quantitative analysis. The sample population is employees } \\
\text { in the service division totaling } 46 \text { employees. Data collection } \\
\text { techniques using survey with questionnaire as instrument. The } \\
\text { data analysis technique used multiple linear regression, t-test } \\
\text { aand F- test to test the hypothesis with the SPSS program. The } \\
\text { resuls of this study shows that competence, compensation and } \\
\text { diciplines as partially and simultaniously significant effect on } \\
\text { employee performance, and the effect of competence on } \\
\text { employee performance is the most significant among the other } \\
\text { three variables. Its indicate that increasing performance of } \\
\text { employees can be determined by competence, compensation and } \\
\text { work discipline of employees at division service PT. United } \\
\text { Motors Centre Suzuki Ahmad Yani Surabaya. }\end{array}$ \\
\hline
\end{tabular}

\section{Introduction}

Human resources in an organization is a very important factor. Human resources are resources that have many advantages compared to other resources in a company. So if the company has competent human resources, then the company will develop rapidly and if the company's human resources are not qualified, the company's development will be hampered. Therefore, the company is said to be successful because it has good quality human resources. Employee performance is the result achieved both in quality and quantity in completing their duties and responsibilities. Therefore, employee performance will run effectively if it is supported by the competence of compensation and work discipline of the employees themselves.

The problem faced by the company is that the performance of employees has not been optimal, especially during the current covid period, the company PT Unilever faces obstacles in achieving optimal performance due to several reasons. The research results stated that employee competence has a significant effect on employee performance [1], as well as research results that are not as expected, discipline is still weak, and other 
problems that arise due to the current situation and conditions, even though work discipline is very influential on employee performance, discipline is implemented to encourage employees to follow various standards and rules, so that irregularities can be prevented. The main objective is to encourage self-discipline among employees to arrive on time. By arriving on time and carrying out tasks according to their duties, it is expected that performance will increase, through discipline will reflect strength, as usual.

To improve the performance of employees, one must pay attention to competence, namely one's work ability which includes aspects of knowledge, skills and work attitudes in accordance with established standards. PT. United Motors Center develops a competency model that integrates with performance appraisal benchmarks based on the knowledge, skills and behavior possessed by each employee of each employee in order to facilitate the implementation of duties and responsibilities effectively and efficiently which will be used as the basis for developing human resources. [2].

In addition to competence, compensation can also improve employee performance in the company [3]. Compensation that is always expected by employees is a form of reward or bonus for services in the form of thoughts and energy in helping the company to achieve performance effectively and efficiently. Compensation can consist of various kinds such as old age benefits, promotions or promotions, salaries, compensation structures, and compensation scales. Work discipline is also important in improving employee performance [4]. Discipline is the observance of the rules that apply in the company for employees who are obliged to comply with the rules or procedures of the company. Employee discipline in the company is an important element in achieving company goals, this is based on the fact that activities in the company always use human labor in addition to machine power. Obedience and obedience in attitudes and behavior that are real at the time of achieving the goals that have been set if supported by high discipline then the success of a job. For that discipline is a factor in achieving performance in the company. Based on the phenomena and empirical studies above, this study aims to determine whether competence, compensation and work discipline affect the performance of employees in the service division of PT. United Motors Center Suzuki Ahmad Yani Surabaya.

\section{Research Methods}

The research used is an explanatory research method, which is a research that intends to explain the position of the variables studied and to relate one variable to another. Explanatory research is carried out with the aim of explaining or proving how the relationship between variables in this study is. The source of data used in this study is primary data, namely the source of data obtained directly from respondents. Primary data sources in this study were obtained by distributing questionnaires to respondents, namely employees in the company as the object of research. The population and sample of this study were all employees in the service division of PT. United Motors Center Suzuki Ahmad Yani Surabaya, totaling 46 people. The sampling technique in this study is a saturated sampling technique, which involves the entire population involved in 
answering the questionnaire given through the google form. Then after the data is collected, it is analyzed using SPSS software which consists of Regression Analysis and hypothesis testing through $\mathrm{t}$-test and F-test.

\section{Result and Discussion}

Theoritical Framework and Hypothesis

a. Competence

Competence is the ability to carry out tasks in accordance with skills and experience related to technology, and can develop work motivation that is relevant in improving its performance [5]. competence can also be defined as characteristic that underlies the individual as a basic trait related to the effectiveness of the individual's performance in his work [6]. However, Competence is the basis for how the work carried out by employees can be carried out in accordance with the demands of the work for which they are responsible. In this case, employees must continue to be able to adapt to be able to have the will so that they meet competency standards according to their field of work [7]. Competence is a skill, fundamental attitude, knowledge, and value possessed by an individual that can be seen from how he thinks or does something consistently.

This shows that competence is not only defined as a person's knowledge or expertise, but also a person's desire to do what he knows, so as to be able to provide benefits [8]. That way, the notion of competence is a combination of knowledge, skills, and personality attributes of each individual, so as to improve their performance and be able to make a good contribution to the success of the company. Employees who have high competence will easily achieve higher performance, this is in accordance with the results of some research which states that employee competence has a significant influence on employee performance, this shows that the higher the employee's competence, the higher the performance obtained [9], as well as research results of others that competence has a significant effect on employee performance [10] and [11].

H1: Competence has a significant effect on employee performance

\section{b. Compensation}

Compensation is all income in the form of money, in the form of goods either directly or indirectly, which is received by employees in return for services provided to the company [12]. Compensation given to employees can be in the form of financial (money) or non-financial (payments, goods, given based on company policy to all employees in an effort to improve employee welfare. Other definer stated that Compensation is a gift or reward given directly or indirectly, financial and nonfinancial, which is fair and appropriate to employees, in return for their services to the company [13].

Compensation given to employees consists of several forms of compensation, in this case it is not only given in the form of money but can also be in the form of non-monetary for example promotion, mutation of positions that are more profitable or perhaps prestigious, or foam also in the form of work facilities [10]. While the form 
of compensation is not only in the form of material but also in the form of allowances. The usual compensation given to employees can be in the following forms [14]:

1. Wages/salaries. Wages are usually related to the hourly rate of pay (the longer the work, the greater the pay). Wages are the most common pay base for production and maintenance workers. While the salary (salary) generally applies to weekly, monthly or yearly rates.

2. Incentives, (incentives) are additional salaries above or outside the salary or wages provided by the organization. Incentive programs are tailored to provide additional pay based on productivity, sales, benefits or cost-cutting efforts.

3. Benefits (Benefits). Examples of benefits such as health insurance, life insurance, vacations covered by the company, pension plans and other benefits related to employment.

4. Facilities are enjoyment/facilities such as company car, club membership, dedicated parking space.

5. Companies provide compensation to their employees for the services that have been provided to the company [15], and it will greatly affect the level of performance of the employees themselves. This is also supported by the other researcher that compensation has an effect on employee performance which measure by financial compensation and non-financial compensation and both have a significant effect on employee performance [16].

H2: Compensation has a significant effect on employee performance c. Work Discipline

Work discipline is a measuring tool used by superiors or managers to interact with employees so that employees are willing to change a behavior as well as an effort to increase one's awareness and willingness to follow all the rules and regulations that apply in the company [18].

Discipline define as a person's awareness and willingness to obey all organizational rules and social norms that apply [19]. Discipline means actions taken with supervision to correct wrong behavior and attitudes on temporary employees [6]. Work discipline is a tool used by managers to communicate with employees so that they are willing to change a behavior as well as an effort to increase one's awareness and willingness to obey all company regulations and applicable social norms [18]. Work discipline can be divided into four dimensions including [6]:

1. Obey the rules of time; Judging from the hours of work, home hours and hours of rest on time in accordance with the rules that apply in the company.

2. Comply with company regulations; Basic rules about how to dress, and behave at work.

3. Obeying the rules of behavior at work Shown by ways of doing jobs according to the position, duties, and responsibilities as well as how to relate to other work units.

4. Obey other regulations; Rules about what employees can and cannot do in the company.

Employees who have high work discipline will produce high performance [20] because with discipline employees can work properly in accordance with the 
right rules and policies. This is also supported by the results of his research [21], which states that the higher the work discipline possessed by the employee, the higher the performance obtained by the employee. Likewise, the results of some research also state that work discipline has a significant effect on employee performance [22].

H3: Work discipline has a significant effect on employee performance

d. Employee Performance

Employee performance is a record of the output produced or obtained on the function of a particular job or activity during a certain period of time with work behavior that is relevant to the company's goals [23]. Employee performance can be define is the result of a process that refers and is measured over a certain period of time based on pre-determined provisions or agreements [20]. Employee performance is the result of work both in quality and quantity achieved by a person in carrying out tasks according to the responsibilities [24]. Performance is a record of the results produced or generated for certain job functions or activities over a certain period of time and a set of behaviors that are relevant to organizational goals [23]. There are five indicators for measuring individual employee performance [24], including:

1. Quality; measured from the employee's perception of the quality of the work produced and the perfection of the task on the skills and abilities of employees.

2. Quantity; is the amount produced expressed in terms such as the number of units, the number of activity cycles completed and the presence of high initiative in completing the work.

3. Punctuality; i.e. the level of activity completed at the beginning of the stated time, from the point of view of coordinating with the output results and maximizing the time available for other activities.

4. Effectiveness; is the level of use of organizational resources (manpower, money, technology, raw materials) maximized with the intention of increasing the output of each unit in the use of resources in accordance with the command.

5. Independence; that is the level of an employee who will later be able to carry out his work functions. Work commitment. Is a level where employees have a commitment to work with the agency and employee responsibilities to the office.

Result: Prior to further analysis, the data was tested for validity and reliability and the results of all question items were valid and each variable also obtained reliable results. Validity test is conducted to measure whether or not a questionnaire is valid. Validity testing is done by calculating the Pearson Product Moment correlation coefficient.

After the data is declared valid and reliable, the classical assumption test is carried out with the result that the normality test is used to determine whether the data population is normally distributed or not. The results of the normality calculation show a normal probability plot with a significance value of the Kolmogorov Smirmov test $>$ $0.05(\mathrm{a}-5 \%)$, it can be stated that the residuals of the regression model are normally distributed.

Heteroscedasticity Test. Calculation of analysis Multicollinearity test was carried out to determine the existence of a strong correlation between the independent variables 
in the regression model. Regression analysis assumes that there is no multicollinearity in the approach model whether or not there is multicollinearity done by looking at the tolerance and VIF values. If the tolerance value is $>0.1$ and $\mathrm{VIF}<10$, then the regression model is not multicollinear. From the results of the classical assumption test, the three variables show a VIF value that is smaller than 10 and a tolerance greater than 0.1 , so it can be said that there is no multicollinearity in the model.

While the classical assumption test of heteroscedasticity is the result of SPSS (Statistical Product and Service Solutions) output through a scatterplot graph between $\mathrm{Z}$ prediction (ZPRED) which is the independent variable ( $\mathrm{X}=\mathrm{Y}$ axis prediction results) and residual value (SRESID) is the dependent variable (axis). $Y=Y$ real). The results of the data distribution show that the data spreads randomly both above and below zero on the $\mathrm{Y}$ axis so that it can be stated that there is no heteroscedasticity. Multiple linear regression analysis was used to measure the effect of each independent variable on the dependent variable. The results of the multiple regression analysis can be seen in table 1.

Table 1 Result of Multiple Linear Regression Analysis and Hypothesis Testingt-test

\begin{tabular}{|c|c|c|c|c|c|c|c|c|}
\hline \multirow[t]{2}{*}{ Model } & \multicolumn{2}{|c|}{$\begin{array}{c}\text { Unstandardized } \\
\text { Coefficients }\end{array}$} & \multirow{2}{*}{$\begin{array}{c}\begin{array}{c}\text { Standardized } \\
\text { Coefficients }\end{array} \\
\text { Beta }\end{array}$} & \multirow[t]{2}{*}{$\mathrm{t}$} & \multirow[t]{2}{*}{ Sig. } & \multicolumn{3}{|c|}{ Correlations } \\
\hline & $\mathrm{B}$ & $\begin{array}{l}\text { Std. } \\
\text { Error }\end{array}$ & & & & $\begin{array}{l}\text { Zero- } \\
\text { order }\end{array}$ & Partial & Part \\
\hline 1(Constant) & -.486 & .217 & & $\begin{array}{l}- \\
2.244\end{array}$ & .030 & & & \\
\hline Competence & .528 & .126 & .421 & 4.205 & .000 & .914 & .544 & .199 \\
\hline Compensation & .434 & 129 & .355 & 3.354 & .002 & .911 & .460 & .158 \\
\hline Job Descipline & .265 & .101 & .230 & 2.608 & 013 & .861 & .373 & .123 \\
\hline
\end{tabular}

Based on the results of the analysis through SPSS as shown in table 1, multiple linear regression equations can be made as follows:

$\mathrm{Y}=-0.486+0.528 \mathrm{X} 1+0.434 \mathrm{X} 2+0.265 \mathrm{X} 3+\mathrm{ei}$

The results of the above equation can be interpreted that the constant value of 0.486 indicates that without the Competence, Compensation and Work Discipline variables, the value of the Employee Performance variable $(Y)$ is -0.486 or minus. However, if the employee's competence is increased by one level, the employee's performance will increase by 0.528 . while the value of the regression coefficient for compensation of 0.434 indicates if there is an increase in compensation of one unit it will cause an increase in employee performance $(\mathrm{Y})$ of 0.434 . Likewise for Work Discipline to get a value of 0.265 , then every increase in work discipline will cause an increase in employee performance $(\mathrm{Y})$ of 0.265 units. Thus it can be said that each $\mathrm{X}$ variable in this study will cause employee performance to increase. This influence is supported by the results of the correlation coefficient $(\mathrm{R})$ of 0.952 , meaning that the relationship between the variables Competence (X1), Compensation (X2), Work Discipline (X3) and employee performance is very strong. It can be said that if the competence, compensation and work discipline of employees increase, their performance will also increase, and the contribution of these variables is $90.6 \%$, so it can be said that it is very high. 
Hypothesis test: To find out or partially test the independent variables on the dependent variable. This calculation using SPSS can know the value of t-test, in table 1, where when viewed from the significance value of each variable it shows a number below 0.05 so that Hypothesis 1, Hypothesis 2 and Hypothesis 3 are accepted. While hypothesis 4 which states that competence, compensation and work discipline simultaneously affect employee performance can be seen in the results of the F-test in table 2.h.

Table 2 Result of Hypothesis Testing with F-Test

\begin{tabular}{lllcll}
\hline \multicolumn{1}{c}{ Model } & Sum of Squares & Df & Mean Square & F & Sig. \\
\hline 1. Regression & 10.934 & 3 & 3.645 & 135.295 & $.000^{\text {a }}$ \\
Residual & 1.131 & 42 & .027 & & \\
Total & 12.065 & 45 & & & \\
\hline
\end{tabular}

To find out or test the effect of the variables together (simultaneously) on the dependent variable, the $F$ test is used. Where the value indicates the level of simultaneous test results of 135,295 . Which is where the significance value is $0.000<0.5$. So this shows that the Competence, Compensation and Work Discipline variables together have a significant effect on Employee Performance.

Discussion:

a. The Effect of Competence on Employee Performance

In testing this hypothesis, a partial test ( $t$ test) is used which is obtained from the Competency variable (X1) which has an influence on Employee Performance (Y). The results of the partial test are known from the significance value in the t-test of the Competency variable $(\mathrm{X} 1)$ of $0.000<0.05$. From the results of the analysis that the Competence variable has a significant influence on employee performance, and it is indicated that if it has the appropriate competence, the employee's performance will be better. The influence of the direction of the employee's competence and performance variables is positive. If good competence is applied to PT United Motors Center Suzuki Ahmad Yani Surabaya, the higher the employee's performance will be. Based on the description above, the first hypothesis which reads "Competence affects employee performance in the service division of PT United Motors Center Suzuki Ahmad Yani Surabaya" is declared to be accepted and proven to be true.

The results in this study are the same as those conducted by previous research by Yulka Cindrawasi (2019), showing that the competence variable has a positive and significant effect on employee performance, besides that it also supports the research of Annisa Putri Soetrisno and Alini Gilang (2018), S. Mujanah et al. (2019) and Sumantri et al (2017) which state that employee competence has a significant influence on employee performance, this shows that the higher the employee competence, the higher the performance obtained.

b. The Effect of Compensation on Employee Performance

Based on the results of testing the second hypothesis using a partial test ( $t$ test), it is obtained that compensation (X2) has an influence on employee performance (Y). This can be seen from the significance value on the t-test of the Compensation variable (X2) of $0.002<0.05$. Based on the results of this analysis, it can be concluded that the Compensation variable has a significant influence on the employee's performance. It 
can be indicated that the existence of high employee performance can be formed by the provision of high and fair compensation. The direction of influence that occurs between the two variables is positive. Based on the description above, it can be concluded that the second hypothesis variable reads "Compensation has an effect on employee performance in the service division of PT United Motors Center Suzuki Ahmad Yani Surabaya" proven to be true and acceptable.

This it can be said that the results of this study confirm the results of Rizky Novianti's research (2017), and Machmed Tun Ganyang and Epo Lestari, (2013) which states that compensation has a significant influence on employee performance.

c. The Effect of Work Discipline on Employee Performance

Based on testing the results of the third hypothesis using a partial test ( $t$ test) obtained from the results of the Work Discipline variable (X3) that has an influence on Employee Performance ( $Y$ ). These results are known from the significance value of the t-test of the Work Discipline variable $(\mathrm{X} 3)$ of $0.013<0.05$. It is known that the results of the analysis of work discipline variables show a significant effect on performance, then performance can be indicated if high employee performance can be formed through high work discipline. The variable of work discipline with employee performance has a positive relationship direction. Based on the description above, the results of the research on the third hypothesis reads "Work discipline affects employee performance in the service division of PT United Motors Center Suzuki Ahmad Yani Surabaya" proven true and can be declared accepted.

The results in this study are in line with the results of previous research conducted by Ali Wairooy (2017) which states that work discipline has a positive and significant effect on employee performance. In addition, it also confirms the research results of Cleopatra, (2015) and Rizki Novriyanti Zahara, and Hajan Hidayat (2017) and the results of his research Eigis Yani Pramularso (2018) also states that work discipline has a significant effect on employee performance.

\section{d. Research Implication}

After analyzing and testing the hypotheses described above, it is necessary to develop policies that are expected to make a theoretical contribution to management practice. Several implications can be derived from the results of this study, namely:

1. Employee performance can be created well if each employee has good work competence, appropriate compensation, and high work discipline. With this research, it can be used for consideration for PT United Motors Center Suzuki Ahmad Yani Surabaya in order to pay attention to employees who have high work competence and maintain and improve the competence and compensation of employees in order to create better performance. Work discipline should be taken into consideration in determining promotions or positions for employees so as to stimulate employee morale at work. In addition, there is an evaluation regarding the issue of work discipline is also needed so that the level of work indiscipline carried out by employees can be reduced.

2. Based on the results of the study, it is hoped that further research can be carried out because there are many things that can be explored in the variables studied, so that they will provide input for other interested parties, especially for the company. And 
for future researchers, they can develop and apply science to what extent the theories have been applied to cases in the field so that things that are felt to be lacking can be improved.

\section{Conclusion}

Based on the analysis and results that have been carried out regarding the influence of competence, compensation and work discipline on employee performance, it can be concluded that competence has a significant effect on employee performance in the service division of PT. United Motors Center Suzuki Ahmad Yani Surabaya. Likewise, compensation and work discipline have a significant effect on employee performance either partially or simultaneously. Thus it can be said that the first, second, third and fourth hypotheses are accepted and proven to be true. Based on the findings of this study, the company that is the object of this research can be optimized for its performance by increasing their competence through mentoring training or other means. In addition, attention to competence can also be done because the function of compensation can increase satisfaction, motivation, morale to achieve optimal employee performance. Work discipline can also be improved through coaching and cultivating discipline so that it can achieve optimal performance. For further researchers, this research is expected to be a reference material, and is expected to be able to examine organizational culture and employee motivation that can improve employee performance to be more optimal.

\section{References}

[1] Dina Rande (2016), Pengaruh Kompetensi Terhadap Kinerja Pegawai pada Dinas Perhubungan, Komunikasi dan Informatika Kabupaten Mamuju Utara. e-Jurnal Katalogis, Volume 4 Nomor 2,Februari 2016 hal 101-109

[2] Mujanah, S., Brahmasari, I. A., Brahma Ratih, I. A. \& Candraningrat, C. (2019). The impact of collective ambition, organizational culture, and organizational commitment on organizational citizenship behavior and the women's cooperatives' performance in East Java Indonesia. International Journal of Civil Engineering and Technology, 10(08).

[3] Agung Surya Dwianto, Pupung Purnamasari, dan Tukini, 2019. Pengaruh Kompensasi Terhadap Kinerja Karyawan Pada PT. JAEIL INDONESIA. Jurnal Ekonomi \& Ekonomi Syariah Vol 2 No 2, hal. 209-223

[4] Hepiana Patmarina, Nuria Erisna, 2012. Pengaruh Disiplin Kerja Terhadap Kinerja Karyawan Yang Dimediasi Oleh Produktivitas Kerja Perusahaan CV. Laut Selatan Jaya Di Bandar Lampung. Jurnal Manajemen dan Bisnis, Vol. 3 no. 1 hal. 19-37.

[5] Karya, D. F., Rasyid, R. A \& Candraningrat, C.(2021). The Effect of Work Interfere family and family interfere work on commitments through satisfaction and motivation. Ekspektra: Jurnal Bisnis dan Manajemen, No 2 Vol 5, Hal. 1-12

[6] Sutrisno, E. 2017. "Manajemen Sumber Daya Manusia". Jakarta: Kencana.

[7] Ance, S. A., Siti, M. \& Candraningrat, (2017). Kompetensi Karyawan, Emotional Quotient Dan Self Efficacy Pengaruhnya Terhadap Organizational Citizenship Behavior Dan Kinerja Karyawan Pada Indomobil Grup Di Sur. JOURNAL Of 
Research In Economics and Management (Jurnal Riset Ekonomi dan Manajemen) Volume, 17.

[8] Mujanah, S., Aini, S. N. \& Candraningrat. C. (2020). Transformational Leadership, Kondisi Kerja dan Budaya Organisasi Pengaruhnya terhadap Kinerja Karyawan. Business and Finance Journal, 5(2), 155-164.

[9] Annisa Putri Soetrisno dan Alini Gilang (2018), Pengaruh Kompetensi Terhadap Kinerja Karyawan (Studi di PT. Telekomunikasi Indonesia Tbk Witel Bandung). Jurnal Riset Bisnis dan Manajemen, Vol. VIII no. 1 hal. 62-74.

[10] S. Mujanah, T. Ratnawati, \& A. Kusmaningtyas (2019) The Effect of Competence, Emotional Quotient, and Financial Quotient on The Business Performance of Small and Medium Enterprises in Surabaya, Indonesia. Proceeding 16th International Symposium on Management, Advance in Social Science, Education and Humanities Reseach Vol 308, hal. 99-102.

[11] SM Iwan Sumantri, Ida Aju Brahmasari, and S Mujanah, (2017). The effect of individual characteristics, competence and quality of work life on work motivation, intention to leave and employee performance outsoursing manufacturing company in East Java Province. Archives of Business Research, Vol5, Issue 5. hal. 115-125

[12] Siti Mujanah, 2019. Manajemen Kompensasi. Surabaya, Penerbit Putra Media Nusantara (PMN)

[13] Marwansyah. (2016). MANAJEMEN SUMBER DAYA MANUSIA. Bandung: Alfabeta.

[14] Irrine Ayu (2015). Manajemen Kompensasi (Pengertian, Jenis dan Tujuan Kompensasi. https://irrineayu.wordpress.com/2015/06/07/manajemenkompensasi-pengertian-jenis-dan- tujuan-kompensasi/. Di download tanggal 12 Juni 2021.

[15] AA. Anwar Prabu Mangkunegara, 2013, Manajemen Sumber Daya Manusia Perusahaan, Bandung. Remaja Rosdakarya.

[16] Machmed Tun Ganyang, dan Epo Lestari (2013). Pengaruh Kompensasi Terhadap Kinerja Karyawan Pada PT. Lane Archive Management Jakarta, Jurnal Lentera Bisnis, VOL. 2 NO. 1 hal. 2252-9993

[17] Stefanus Andi Pratama; Moehammad Soe'oed Hakam dan Gunawan Eko Nurtjahjono, (2015), Pengaruh Kompensasi Terhadap Kinerja Karyawan (Studi pada karyawan PT. Asuransi Jiwasraya persero regional office Malang). Jurnal Administrasi Bisnis (JAB), Vol. 25 No. 1, hal. 1-8.

[18] Rivai, Veithzal; Sagala, Ella Jauvani (2013), Sumberdaya Manusia untuk Perusahaan dari Teori ke Praktik, Jakarta: Rajawali Pers

[19] Hasibuan, Malayu. S.P. 2016. "Manajemen Sumber Daya Manusia. Edisi Revisi". Jakarta: PT. Bumi Aksara.

[20] Cleopatra, 2015. Pengaruh Disiplin Kerja Terhadap Kinerja Karyawan Pada Pabrik Kerupuk Naga Mas Pematangsiantar. Jurnal Sultanist, Vol. 3, No. 1, JUNI 2015

[21] Novriyanti, Rizki, Zahara dan hajan hidayat "Pengaruh kepuasan dan disiplin kerja terhadap kinerja Karyawan bank di kota batam. Jurnal Polibatam, Volume 2 No 
https://jurnal.polibatam.ac.id/index.php/JAMA/article/download/500/349.d di akses pada 2 Mei 2021

[22] Pramularso, E. Y. (2018). Pengaruh Kompetensi terhadap Kinerja Karyawan CV Inaura Anugerah Jakarta.

[23] Sudarmanto, 2014, Kinerja dan Pengembangan Kompensasi SDM, Pustaka pelajar, Yogyakarta

[24] Robbins, Stephen P. and Mary Coulter. 2012. "Management, Eleventh Edition". United States of America: Pearson Education Limited. 